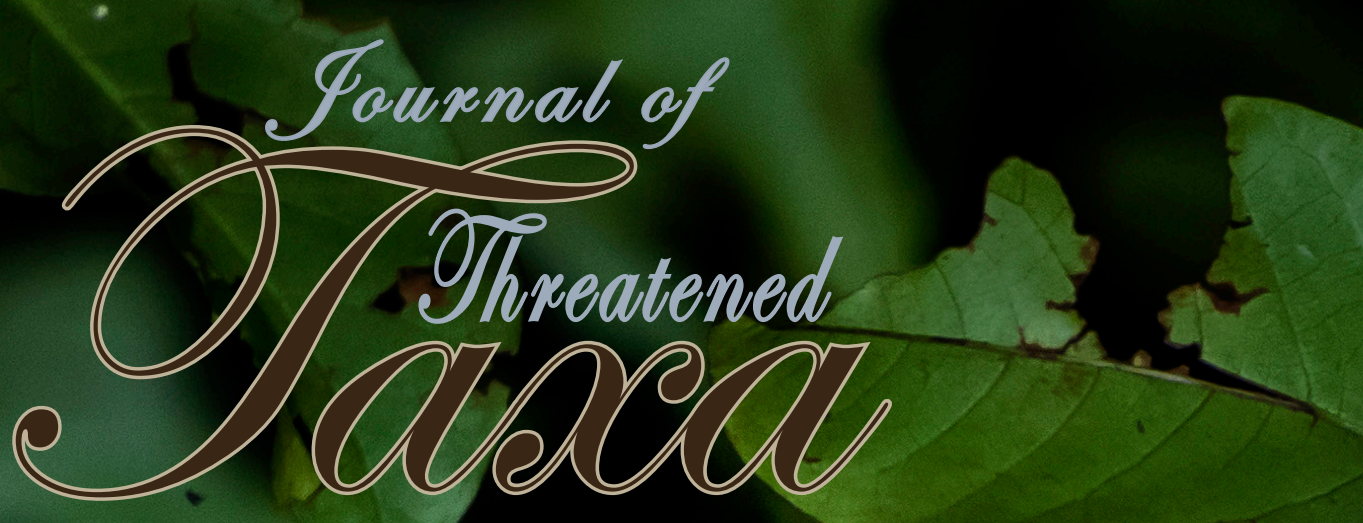

Building exidence for conservation glabally

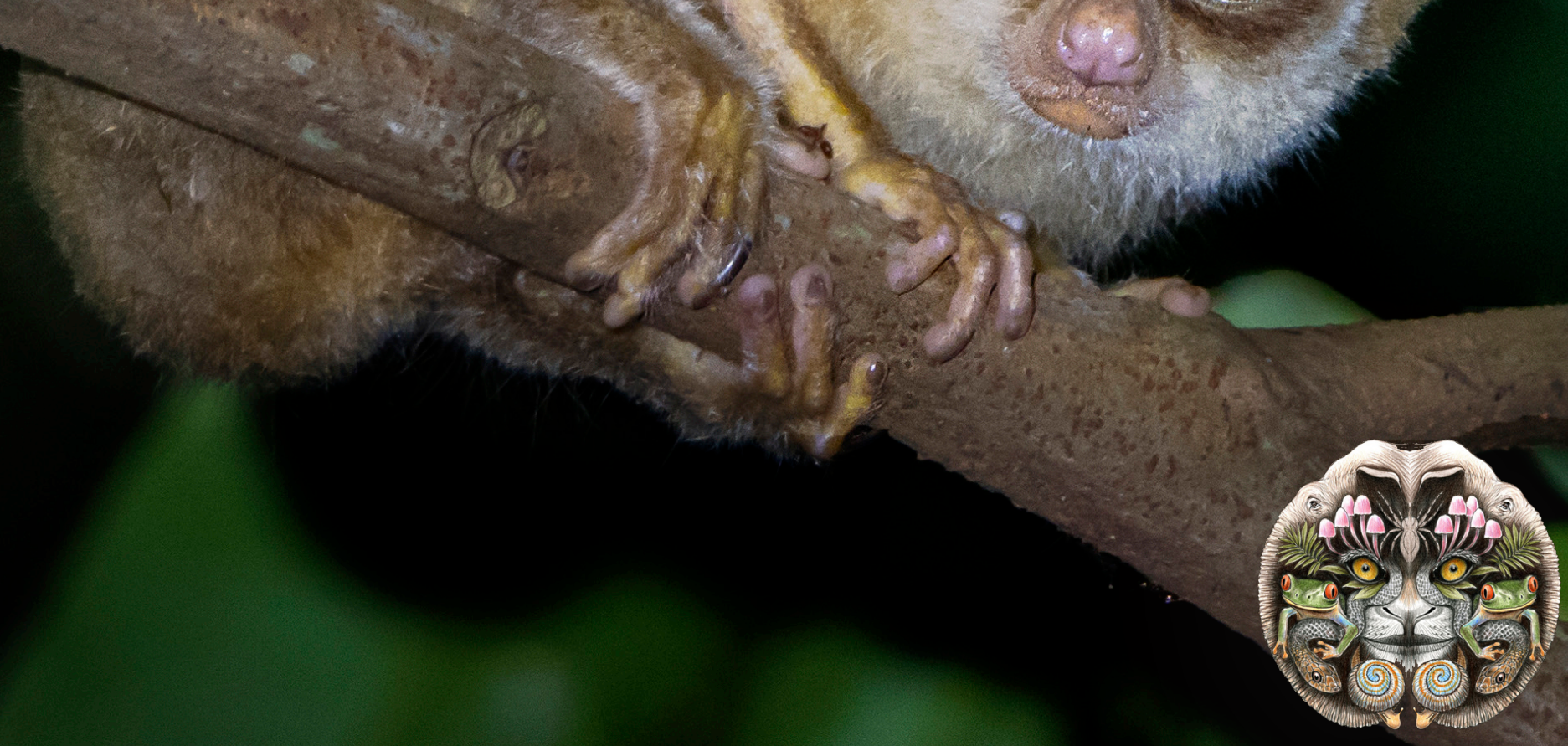

Open Access

$10.11609 /$ jott.2021.13.010.19431-19614 creven.threatenedtaxa.arg

26 September 2021 (Online \& Print) Val. 13 | Na. 11 | Pages: 19431-19674 


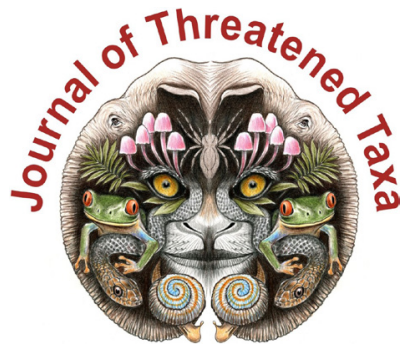

ISSN 0974-7907 (Online); ISSN $0974-7893$ (Print)

Publisher

Host

Wildlife Information Liaison Development Society

www.wild.zooreach.org

Zoo Outreach Organization www.zooreach.org

No. 12, Thiruvannamalai Nagar, Saravanampatti - Kalapatti Road, Saravanampatti, Coimbatore, Tamil Nadu 641035, India

Ph: +91 9385339863 | www.threatenedtaxa.org

Email: sanjay@threatenedtaxa.org

EDITORS

\section{Founder \& Chief Editor}

Dr. Sanjay Molur

Wildlife Information Liaison Development (WILD) Society \& Zoo Outreach Organization (ZOO)

12 Thiruvannamalai Nagar, Saravanampatti, Coimbatore, Tamil Nadu 641035, India

\section{Deputy Chief Edito}

Dr. Neelesh Dahanukar

Noida, Uttar Pradesh, India

\section{Managing Editor}

Mr. B. Ravichandran, WILD/ZOO, Coimbatore, India

\section{Associate Editors}

Dr. Mandar Paingankar, Government Science College Gadchiroli, Maharashtra 442605, India

Dr. Ulrike Streicher, Wildlife Veterinarian, Eugene, Oregon, USA

Ms. Priyanka Iyer, ZOO/WILD, Coimbatore, Tamil Nadu 641035, India

Dr. B. A. Daniel, $200 / \mathrm{WILD}$, Coimbatore, Tamil Nadu 641035, India

\section{Editorial Board}

Dr. Russel Mittermeier

Executive Vice Chair, Conservation International, Arlington, Virginia 22202, USA

\section{Prof. Mewa Singh Ph.D., FASc, FNA, FNASc, FNAPsy}

Ramanna Fellow and Life-Long Distinguished Professor, Biopsychology Laboratory, and Institute of Excellence, University of Mysore, Mysuru, Karnataka 570006, India; Honorary Professor, Jawaharlal Nehru Centre for Advanced Scientific Research, Bangalore; and Adjunct Professor, National Institute of Advanced Studies, Bangalore

\section{Stephen D. Nash}

Scientific Illustrator, Conservation International, Dept. of Anatomical Sciences, Health Sciences Center, T-8, Room 045, Stony Brook University, Stony Brook, NY 11794-8081, USA

\section{Dr. Fred Pluthero}

Toronto, Canada

\section{Dr. Priya Davidar}

Sigur Nature Trust, Chadapatti, Mavinhalla PO, Nilgiris, Tamil Nadu 643223, India

\section{Dr. Martin Fisher}

Senior Associate Professor, Battcock Centre for Experimental Astrophysics, Cavendish

Laboratory, JJ Thomson Avenue, Cambridge CB3 OHE, UK

\section{Dr. John Fellowe}

Honorary Assistant Professor, The Kadoorie Institute, 8/F, T.T. Tsui Building, The University of Hong Kong, Pokfulam Road, Hong Kong

\section{Prof. Dr. Mirco Solé}

Universidade Estadual de Santa Cruz, Departamento de Ciências Biológicas, Vice-coordenado do Programa de Pós-Graduação em Zoologia, Rodovia Ilhéus/Itabuna, Km 16 (45662-000)

Salobrinho, Ilhéus - Bahia - Brasil

\section{Dr. Rajeev Raghavan}

Professor of Taxonomy, Kerala University of Fisheries \& Ocean Studies, Kochi, Kerala, India

\section{English Editors}

Mrs. Mira Bhojwani, Pune, India

Dr. Fred Pluthero, Toronto, Canad

Mr. P. Ilangovan, Chennai, India

Web Maintenance

Mrs. Latha G. Ravikumar, ZOO/WILD, Coimbatore, India

\section{Typesetting}

Mr. Arul Jagadish, ZOO, Coimbatore, India

Mrs. Radhika, ZOO, Coimbatore, India

Mrs. Geetha, ZOO, Coimbatore India

\section{Fundraising/Communications}

Mrs. Payal B. Molur, Coimbatore, India

Subject Editors 2018-2020

Fungi

Dr. B. Shivaraju, Bengaluru, Karnataka, India

Dr. R.K. Verma, Tropical Forest Research Institute, Jabalpur, India

Dr. Vatsavaya S. Raju, Kakatiay University, Warangal, Andhra Pradesh, India

Dr. M. Krishnappa, Jnana Sahyadri, Kuvempu University, Shimoga, Karnataka, India

Dr. K.R. Sridhar, Mangalore University, Mangalagangotri, Mangalore, Karnataka, India

Dr. Gunjan Biswas, Vidyasagar University, Midnapore, West Bengal, India

Plants

Dr. G.P. Sinha, Botanical Survey of India, Allahabad, India

Dr. N.P. Balakrishnan, Ret. Joint Director, BSI, Coimbatore, India

Dr. Shonil Bhagwat, Open University and University of Oxford, UK

Prof. D.J. Bhat, Retd. Professor, Goa University, Goa, India

Dr. Ferdinando Boero, Università del Salento, Lecce, Italy

Dr. Dale R. Calder, Royal Ontaro Museum, Toronto, Ontario, Canada

Dr. Cleofas Cervancia, Univ. of Philippines Los Baños College Laguna, Philippines

Dr. F.B. Vincent Florens, University of Mauritius, Mauritius

Dr. Merlin Franco, Curtin University, Malaysia

Dr. V. Irudayaraj, St. Xavier's College, Palayamkottai, Tamil Nadu, India

Dr. B.S. Kholia, Botanical Survey of India, Gangtok, Sikkim, India

Dr. Pankaj Kumar, Kadoorie Farm and Botanic Garden Corporation, Hong Kong S.A.R., China

Dr. V. Sampath Kumar, Botanical Survey of India, Howrah, West Bengal, India

Dr. A.J. Solomon Raju, Andhra University, Visakhapatnam, India

Dr. Vijayasankar Raman, University of Mississippi, USA

Dr. B. Ravi Prasad Rao, Sri Krishnadevaraya University, Anantpur, India

Dr. K. Ravikumar, FRLHT, Bengaluru, Karnataka, India

Dr. Aparna Watve, Pune, Maharashtra, India

Dr. Qiang Liu, Xishuangbanna Tropical Botanical Garden, Yunnan, China

Dr. Noor Azhar Mohamed Shazili, Universiti Malaysia Terengganu, Kuala Terengganu, Malaysia Dr. M.K. Vasudeva Rao, Shiv Ranjani Housing Society, Pune, Maharashtra, India

Prof. A.J. Solomon Raju, Andhra University, Visakhapatnam, India

Dr. Mandar Datar, Agharkar Research Institute, Pune, Maharashtra, India

Dr. M.K. Janarthanam, Goa University, Goa, India

Dr. K. Karthigeyan, Botanical Survey of India, India

Dr. Errol Vela, University of Montpellier, Montpellier, France

Dr. P. Lakshminarasimhan, Botanical Survey of India, Howrah, India

Dr. Larry R. Noblick, Montgomery Botanical Center, Miami, USA

Dr. K. Haridasan, Pallavur, Palakkad District, Kerala, India

Dr. Analinda Manila-Fajard, University of the Philippines Los Banos, Laguna, Philippines

Dr. P.A. Sinu, Central University of Kerala, Kasaragod, Kerala, India

Dr. Afroz Alam, Banasthali Vidyapith (accredited A grade by NAAC), Rajasthan, India

Dr. K.P. Rajesh, Zamorin's Guruvayurappan College, GA College PO, Kozhikode, Kerala, India

Dr. David E. Boufford, Harvard University Herbaria, Cambridge, MA 02138-2020, USA

Dr. Ritesh Kumar Choudhary, Agharkar Research Institute, Pune, Maharashtra, India

Dr. Navendu Page, Wildlife Institute of India, Chandrabani, Dehradun, Uttarakhand, India

Invertebrates

Dr. R.K. Avasthi, Rohtak University, Haryana, India

Dr. D.B. Bastawade, Maharashtra, India

Dr. Partha Pratim Bhattacharjee, Tripura University, Suryamaninagar, India

Dr. Kailash Chandra, Zoological Survey of India, Jabalpur, Madhya Pradesh, India

Dr. Ansie Dippenaar-Schoeman, University of Pretoria, Queenswood, South Africa

Dr. Rory Dow, National Museum of natural History Naturalis, The Netherlands

Dr. Brian Fisher, California Academy of Sciences, USA

Dr. Richard Gallon, llandudno, North Wales, LL30 1UP

Dr. Hemant V. Ghate, Modern College, Pune, India

Dr. M. Monwar Hossain, Jahangirnagar University, Dhaka, Bangladesh

Mr. Jatishwor Singh Irungbam, Biology Centre CAS, Branišovská, Czech Republic

Dr. lan J. Kitching Natural History Museum, Cromwell Road, UK

Dr. George Mathew, Kerala Forest Research Institute, Peechi, India

Dr. John Noyes, Natural History Museum, London, UK

For Focus, Scope, Aims, and Policies, visit https://threatenedtaxa.org/index.php/JoTT/aims_scope
For Article Submission Guidelines, visit https://threatenedtaxa.org/index.php/JoTT/about/submissions
For Policies against Scientific Misconduct, visit https://threatenedtaxa.org/index.php/JoTT/policies_various 


\title{
First record of the Eastern Cat Snake Boiga gocool (Gray, 1835) (Squamata: Colubridae) from Tripura, India
}

\author{
Sumit Nath ${ }^{1}\left(\mathbb{D}\right.$, Biswajit Singh $^{2}(\mathbb{D})$ Chiranjib Debnath $^{3}$ (D) \& Joydeb Majumder ${ }^{4}(\mathbb{D})$ \\ ${ }^{1,3}$ Herpetofauna Conservation and Research Division, Wild Tripura Foundation, Dhaleshwar, Road No. 13, Agartala, Tripura, India. \\ ${ }^{2}$ Department of Ecology and Environmental Science, Assam University, Silchar, Assam 788011, India. \\ ${ }^{4}$ Department of Zoology, Ecology \& Biosystematics Laboratory, Tripura University, Tripura 799022, India. \\ ${ }^{1}$ nathsumit389@gmail.com (corresponding author), ${ }^{2}$ biswajitsingh87@gmail.com, ${ }^{3}$ chiranjibbiologist@gmail.com, \\ ${ }^{4}$ jmtugemo@gmail.com
}

Northeastern India has a rich herpetofaunal diversity, with 102 species of snakes, represented by six families comprising 42 genera (Ahmed et al. 2009; Aengals et al. 2018) with some new snake genera and species recently discovered in, e.g., Blythia hmuifang, Pareas modestus, Gongylosoma scriptum, Smithophis atemporalis, Hebius lacrima, Trimeresurus salazar, Trachischium aptei, Trimeresurus arunachalensis, Smithophis arunachalensis, Hebius pealii (Vogel et al. 2017, 2020; Lalremsanga 2018; Bhosale et al. 2019; Captain 2019; Giri et al. 2019; Purkayastha \& David 2019; Das et al. 2020; Mirza et al. 2020). Tripura is a landlocked, small, hilly state surrounded by Assam \& Mizoram of India and Bangladesh on three sides (Image 1). So far, 21 species of snakes under 19 genera and six families have been reported from the state (Majumder 2012; Purkayastha et al. 2020). Earlier, only one species of the genus Boiga, $B$. ochracea was recorded from the state (Majumder et al. 2012; Purkayastha et al. 2020).

Boiga gocool (Gray, 1835) is a nocturnal, arboreal, mildly venomous snake that occurs in tropical semievergreen and degraded forests, tall grasslands, and tea gardens at lower elevations of $50-1,000 \mathrm{~m}$ (Das et al.
2010; Wallach et al. 2014). It feeds mainly on lizards but sometimes also on small birds and mammals. Boiga gocool is poorly known, has a narrow distribution, and is thus rarely reported in regional inventory reports with only a few preserved specimens in scientific collections (Das et al. 2010). This is a southern Asian species having definite distribution records from northern and eastern India, Bangladesh, and Bhutan (Ahsan et al. 2015; Das et al. 2016). Of late, a few records of this species were reported from many other places. In India, B. gocool is reported from Assam- Manas National Park, Guwahati (Purkayastha et al. 2011), Kaziranga National Park (Das et al. 2007), Arunachal Pradesh, Manipur, Meghalaya, Nagaland (Das et al. 2007; Bhupathy et al. 2013), Sikkim (Chettri et al. 2011), West Bengal (Das et al. 2007), northern Odisha (Mohalik et al. 2020), and Uttar Pradesh (Choure et al. 2020). It has been listed as Schedule IV species under the Indian Wildlife (Protection) Act, 1972 (Ahmed et al. 2009) whereas under IUCN Red List category, it stands as 'Not Evaluated'.

In this note, we report our sighting of $B$. gocool in Tripura state. The current survey site is situated within the Khowai district of Tripura (24.064N \& 91.596E;

Citation: Nath, S., B. Singh, C. Debnath \& J. Majumder (2021). First record of the Eastern Cat Snake Boiga gocool (Gray, 1835) (Squamata: Colubridae) from Tripura, India. Journal of Threatened Taxa 13(11): 19652-19656. https://doi.org/10.11609/jott.7051.13.11.19652-19656

Copyright: ( Nath et al. 2021. Creative Commons Attribution 4.0 International License. JoTT allows unrestricted use, reproduction, and distribution of this article in any medium by providing adequate credit to the author(s) and the source of publication.

Funding: Wild Tripura Foundation.

Competing interests: The authors declare no competing interests.

Acknowledgements: Authors express their earnest thanks to Mr. Pallab Chakraborty, director of Sepahijala Zoological Park, Sepahijala, Tripura, India for helping in identification of the species and Wild Tripura Foundation, Tripura, India for help to study the herpetofaunal diversity of Tripura. 

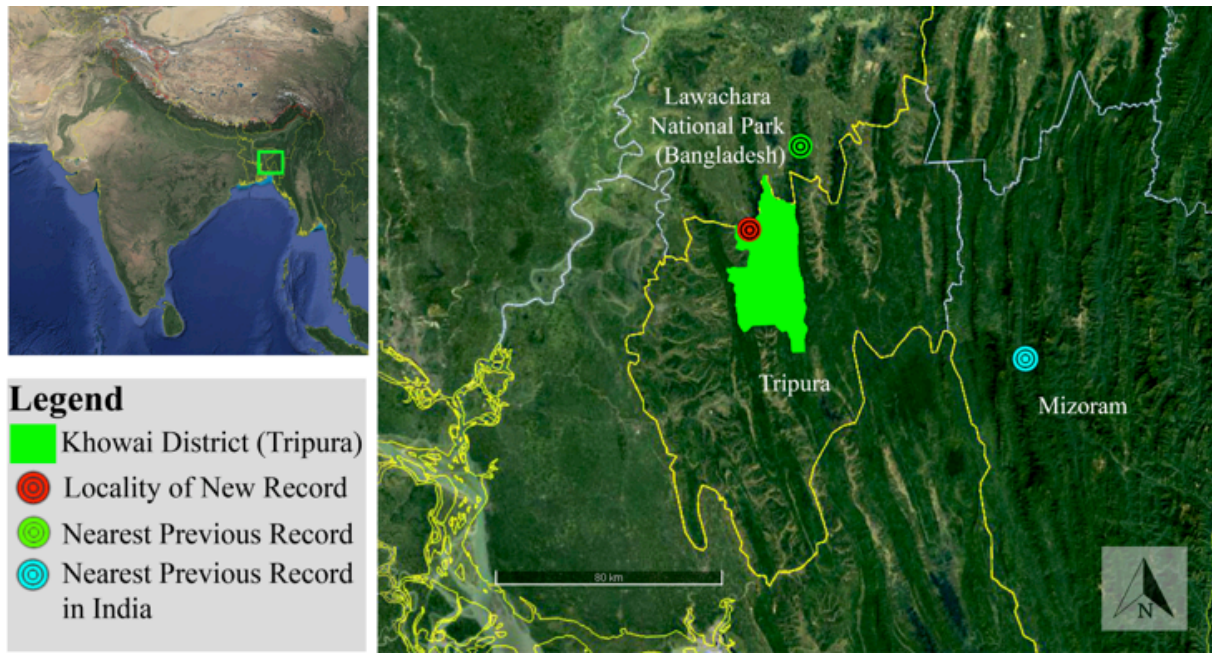

Image 1. Showing new locality record of B. gocool in India and its nearest previous records. (C) Google maps.
$129 \mathrm{~m})$, the forest patch of the survey area was primarily mixed moist deciduous type (Choudhary et al. 2019) having tree species like Tectona grandis, Shorea robusta, Dalbergia sissoo, Bombax ceiba, Phayllanthus emblica, and Mangifera indica spread over an undulating terrain with moderate canopy cover.

The observation made by us was based on opportunistic sightings in the field. On 12 July 2020, during a field visit to Khowai, we noticed a snake passing by near the Khowai river bridge at evening $1539 \mathrm{~h}$. The snake was restrained using a snake hook with utmost safety for making morphological observations and measurements. Photographs were taken using DSLR camera. The length of the individual from snout to vent (SVL) was measured by measuring tape. Gender was confirmed by observing everted hemipenis of the individual and subsequently, the snake was released where it was initially observed.

The recorded individual showed morphological characters as follows: triangular head, distinctly broader than the neck; dorso-laterally compressed body consisting of yellowish-brown dorsal colour with paired dorsolateral series of 45 black vertical Y-shaped markings on the either side which was separated from one another only by the light yellowish vertebral scale row; black markings edged with white; anterior-most six Y-shaped markings fused to form small black lines; markings broken down to small black spots posteriorly; tail with a few small irregular brownish spots, but without markings towards the tip; a large dark brownish arrow-shaped mark with darker edges begins at the posterior part of the inter-nasals, covering the top of the head; an arrow shaped mark followed by black, round spot on nape (Image 2a); a black postocular stripe extending from jaw angle to neck, ending at lower $3^{\text {rd }}$ dorsal scale row; supra-labials and infra-labials white, with small black markings on sutures; pupil black with yellow iris; ventral yellowish-white with small black spots at the lateral edges (Image $2 \mathrm{~b}$ ). The gender of the individual was confirmed as male, by observing everted hemipenis. The length of the individual from snout to vent (SVL) measured $652 \mathrm{~mm}$ and tail length (TL) was 165 $\mathrm{mm}$. Comparing the above data with the identification keys and descriptions specified in standard literature (Whitaker \& Captain 2008; Ahmed et al. 2009; Das et al. 2010; Mohalik et al. 2020) the snake was positively identified as Boiga gocool.

Comparing the morphological characteristics between the known Boiga species in northeastern India, it is evident that the dorsolateral series of 4550 dark brownish and whitish edged $\mathrm{Y}$ or $\mathrm{T}$ shaped marks, divided by distinct light vertebral scale row and a narrow black diamond or circular shaped nuchal dot, that never reaches to the sides of the body were major distinguishing characteristics of B. gocool (Table 1). In the past, much confusion existed regarding distinguishing between $B$. gocool and its closely related and one of the most widely distributed yet poorly studied congener in Indian subcontinent, B. t. trigonata (Das et al. 2010). Regardless, $B$. gocool has a lot in common with $B$. $t$. trigonata in terms of habits, body proportions, and skin colour, but gocool can be differentiated from trigonata by strongly enlarged vertebral scales and an entirely distinct head and dorsal body colour pattern, and dorsolateral series of 45-50 dark brownish and whitish edged Y-shaped marks which are prominently divided by a light vertebral scale row; whereas $B$. trigonata has yellow to whitish, dark edged, angular markings, 
Table 1. Morphological comparisons of body (dorsal and ventral), head and tail morphology between B. gocool and other congeneric species from the Indo-Burma hotspot.

\begin{tabular}{|c|c|c|c|c|c|}
\hline Species & Dorsal body & Ventral body & Head and tail & $\begin{array}{l}\text { Distribution in Indo- } \\
\text { Burma }\end{array}$ & References \\
\hline gocool & $\begin{array}{l}\text { Dorsal colour yellowish- } \\
\text { brown; dorsolateral } \\
\text { series of } 45-50 \text { dark } \\
\text { brownish and whitish } \\
\text { edged Y or T shaped } \\
\text { marks. }\end{array}$ & $\begin{array}{l}\text { Light yellowish- brown } \\
\text { ventral colour with small } \\
\text { dark brown margins or } \\
\text { pattern less. }\end{array}$ & $\begin{array}{l}\text { Head noticeably larger } \\
\text { than neck; wide eye } \\
\text { with vertical pupil, long } \\
\text { tail. }\end{array}$ & $\begin{array}{l}\text { Arunachal Pradesh, } \\
\text { Assam, Nagaland, } \\
\text { Manipur, Mizoram, } \\
\text { Bhutan, and Bangladesh. }\end{array}$ & $\begin{array}{l}\text { Das et al. 2010; Das et } \\
\text { al. 2016; Lalremsanga } \\
\text { \& Lalronunga 2017; } \\
\text { Whitaker \& Captain } \\
2008\end{array}$ \\
\hline cyanea & $\begin{array}{l}\text { Dorsal colour uniform } \\
\text { green or greyish- or } \\
\text { bluish-green; black } \\
\text { Interscale colour, same } \\
\text { colour on the head and } \\
\text { few dorsal scales. }\end{array}$ & $\begin{array}{l}\text { Greenish- or yellowish- } \\
\text { white belly; subcaudal } \\
\text { scales are paired in a } \\
\text { zig-zag pattern. }\end{array}$ & $\begin{array}{l}\text { Head triangular with } \\
\text { rounded tip, distinctly } \\
\text { wider than body. Top } \\
\text { of the head is normally } \\
\text { same colour as the } \\
\text { dorsal or has a brownish } \\
\text { hue. Like other arboreal } \\
\text { snakes, long thin tail } \\
\text { with pointed tip. }\end{array}$ & $\begin{array}{l}\text { Arunachal Pradesh, } \\
\text { Assam, Meghalaya, } \\
\text { Mizoram, Sikkim, } \\
\text { Bangladesh, and Bhutan. }\end{array}$ & $\begin{array}{l}\text { Das et al. 2010; } \\
\text { Lalremsanga \& } \\
\text { Lalronunga 2017; } \\
\text { Whitaker \& Captain } \\
2008\end{array}$ \\
\hline multifasciata & $\begin{array}{l}\text { Dorsal pattern made } \\
\text { up of narrow black } \\
\text { irregular transverse } \\
\text { bands separated by } \\
\text { reddish-brown vertebral } \\
\text { scale lines. }\end{array}$ & $\begin{array}{l}\text { Ventral surface greyish- } \\
\text { to reddish-brown. }\end{array}$ & $\begin{array}{l}\text { Head wider than neck; } \\
\text { large eye has vertical } \\
\text { pupil. Long tail. Two } \\
\text { black lines run across } \\
\text { the top of the head; } \\
\text { another runs down the } \\
\text { neck, a black stripe runs } \\
\text { behind the eye. }\end{array}$ & $\begin{array}{l}\text { Arunachal Pradesh and } \\
\text { Sikkim. }\end{array}$ & $\begin{array}{l}\text { Tshewang, \& Letro } \\
\text { 2018; Das et al. 2010; } \\
\text { Whitaker \& Captain } \\
2008\end{array}$ \\
\hline multomaculata & $\begin{array}{l}\text { Dorsal colour is greyish- } \\
\text { brown with dark brown } \\
\text { markings, black edges, } \\
\text { and brown; double } \\
\text { series of conspicuous } \\
\text { spots present. }\end{array}$ & $\begin{array}{l}\text { Ventral colour is greyish- } \\
\text { brown or impure white, } \\
\text { marked with brown } \\
\text { spots. }\end{array}$ & $\begin{array}{l}\text { Head noticeably larger } \\
\text { than neck; eye with } \\
\text { vertical pupil; long tail. }\end{array}$ & $\begin{array}{l}\text { Arunachal Pradesh, } \\
\text { Assam, Nagaland, and } \\
\text { Bangladesh. }\end{array}$ & $\begin{array}{l}\text { Das et al. 2010; } \\
\text { Whitaker \& Captain } \\
2008\end{array}$ \\
\hline ochracea & $\begin{array}{l}\text { Dorsal body coral red, } \\
\text { reddish- or yellowish- } \\
\text { brown. }\end{array}$ & $\begin{array}{l}\text { Scales on the anterior } \\
\text { belly are yellow, while } \\
\text { those on the mid-body } \\
\text { and tail tip are light } \\
\text { brown. }\end{array}$ & $\begin{array}{l}\text { Head larger than neck; } \\
\text { wide eye with vertical } \\
\text { pupil; tail long and thin. }\end{array}$ & $\begin{array}{l}\text { Sikkim, Assam, Tripura, } \\
\text { Mizoram, Bhutan, and } \\
\text { Bangladesh. }\end{array}$ & $\begin{array}{l}\text { Das et al. 2010; } \\
\text { Lalremsanga \& } \\
\text { Lalronunga 2017; } \\
\text { Majumder et al. 2012; } \\
\text { Whitaker \& Captain } \\
2008\end{array}$ \\
\hline quincunciata & $\begin{array}{l}\text { Fine dark brown spots } \\
\text { and a dark brown } \\
\text { vertebral series make up } \\
\text { the dorsal pattern. }\end{array}$ & $\begin{array}{l}\text { Outer edges of the } \\
\text { ventral surface are } \\
\text { yellowish-white with } \\
\text { white or brown spots }\end{array}$ & $\begin{array}{l}\text { Three longitudinal } \\
\text { stripes on the nape; } \\
\text { head and neck distinct; } \\
\text { body slender and } \\
\text { elongated; eyes wide } \\
\text { with vertical pupil. }\end{array}$ & $\begin{array}{l}\text { Arunachal Pradesh, } \\
\text { Assam, Mizoram, and } \\
\text { Bhutan. }\end{array}$ & $\begin{array}{l}\text { Chaida et al. 2020; Das } \\
\text { et al. 2010; Lalremsanga } \\
\text { \& Lalronunga } 2017\end{array}$ \\
\hline siamensis & $\begin{array}{l}\text { Dorsal body yellowish- } \\
\text { brown; many large black } \\
\text { or dark brown oblique } \\
\text { bands or V-shaped } \\
\text { markings. }\end{array}$ & $\begin{array}{l}\text { Ventral surface } \\
\text { yellowish- or greyish- } \\
\text { brown, with small dark } \\
\text { brown spots present } \\
\text { sometimes. }\end{array}$ & $\begin{array}{l}\text { Head wider than neck; } \\
\text { large eye has vertical } \\
\text { pupil; tail long. }\end{array}$ & $\begin{array}{l}\text { Arunachal Pradesh, } \\
\text { Assam, Mizoram, } \\
\text { Meghalaya, Sikkim, } \\
\text { Nagaland, and } \\
\text { Bangladesh. }\end{array}$ & $\begin{array}{l}\text { Das et al. 2010; } \\
\text { Lalremsanga \& } \\
\text { Lalronunga 2017; } \\
\text { Whitaker \& Captain } \\
2008\end{array}$ \\
\hline trigonata & $\begin{array}{l}\text { Dorsal colour brown } \\
\text { or tan; darker zigzag } \\
\text { markings that are } \\
\text { possibly connected. }\end{array}$ & $\begin{array}{l}\text { Underside of each belly } \\
\text { scale white or tan, small } \\
\text { black spots on the outer } \\
\text { edges. }\end{array}$ & $\begin{array}{l}\text { Head wider than neck; } \\
\text { Large eye with vertical } \\
\text { pupil; tail long; distinct } \\
\text { pale Y-shaped mark } \\
\text { appears on top of the } \\
\text { head, which often black- } \\
\text { edged. }\end{array}$ & Sikkim. & Das et al. 2010 \\
\hline
\end{tabular}

with irregular branching across the vertebral scale row, often connected in a zigzag manner. The sole congener of $B$. gocool recorded from the state was $B$. ochracea (Majumder et al. 2012; Purkayastha et al. 2020) which can be readily distinguished without confusion from $B$. gocool by its patternless or indistinct dark transverse dorsolateral bands on coral red, reddish- or yellowishbrown dorsal body (Table 1).

With the centre of radiation of $B$. gocool lying in the plains and low hills of north and south of the Brahmaputra valley, Assam, (Das et al. 2010), recent records of B. gocool from Odisha (Mohalik et al. 2020) and Uttar Pradesh (Choure et al. 2020), extend its known distribution range further to the south and west, respectively. The current record of $B$. gocool from Tripura eventually fills the void in its northeastern Indian distribution. The present survey site is about $40 \mathrm{~km}$ north-east from Agartala, the state capital and about $35 \mathrm{~km}$ south to the 

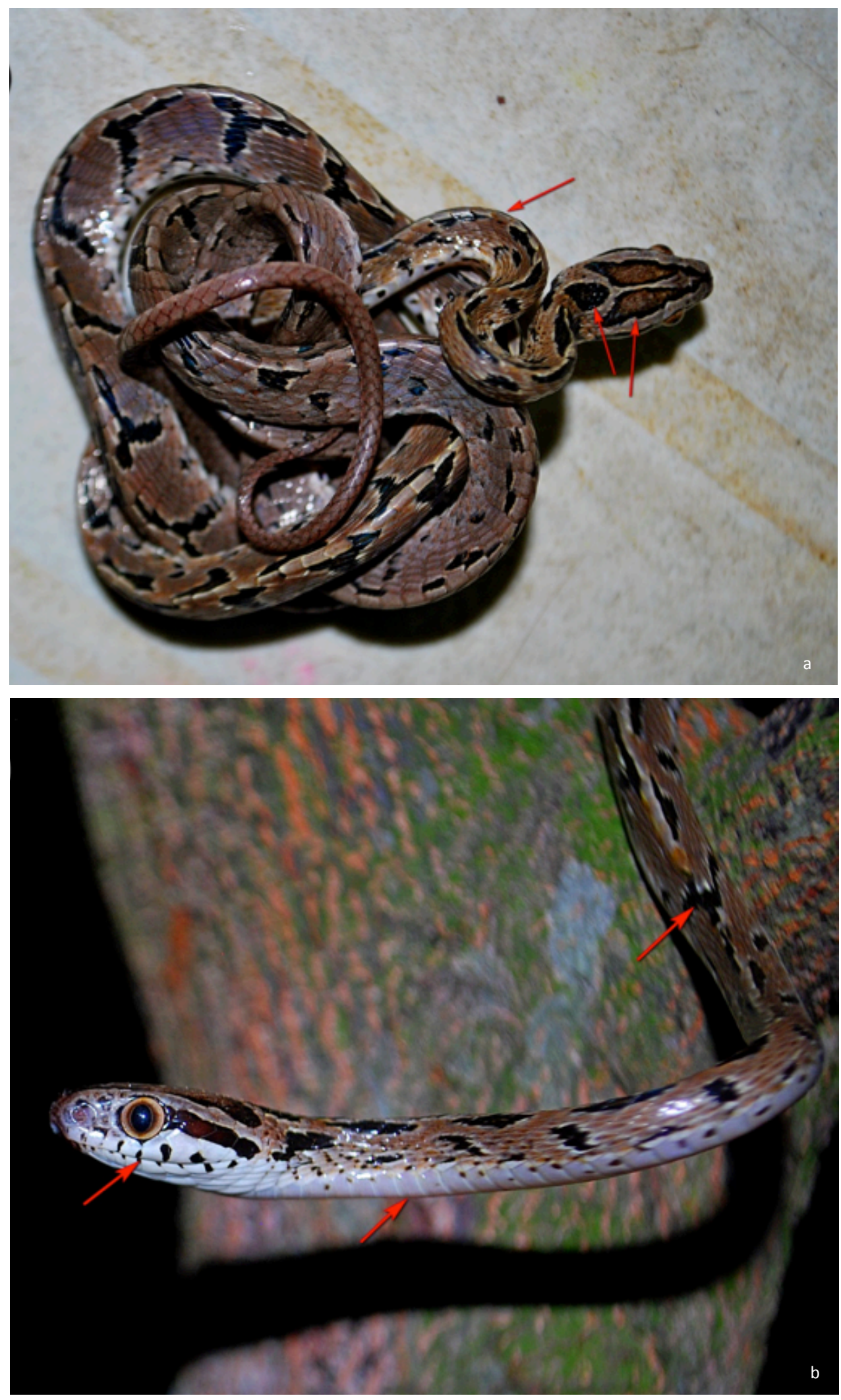

Image 2. Boiga gocool with identification marks: a-Black Y-shaped vertical markings with white edges on either side separated from one another only by pale yellowish vertebral scale row; anterior most Y-shaped markings fused to form small black lines; dark brownish arrowshaped mark covering the top of the head followed by a black, somewhat round-shaped spot on the nape | $b-B l a c k$ postocular stripe; white supralabials and infralabials with small black markings on their sutures; black pupil with yellow coloured iris; yellowish-white ventral with small black spots at the outer lateral edges. (৫ Sumit Nath). 
nearest previously recorded locality for the species from Lawachara National Park, Sylhet District, Bangladesh (Rahman et al. 2013). The nearest occurrence of $B$. gocool from the present survey site, within northeastern India, is that of Mizoram (Lalremsanga \& Lalronunga 2017; Choure et al. 2020). Despite being situated in the Indo-Burma biodiversity hotspot, Tripura is rather poorly studied from the herpetofauna assessment viewpoint. Most of the herpetofaunal studies were limited to a few taxa and locations of the state (Majumder et al. 2012; Purkayastha et al. 2020). Before the current record, only one species of the genus Boiga (B. ochracea) was reported from Tripura, whereas eight representatives of the genus have been reported and found to be occurring in northeastern India, partly sympatric with $B$. gocool (Table 1). Hence, the first record of $B$. gocool from this state will contribute towards updating the checklist of the herpetofauna of Tripura. Future studies on the genus Boiga and other snake species sympatric with $B$. gocool throughout the state is much needed.

\section{References}

Aengals, R., V.S. Kumar, M.J. Palot \& S.R. Ganesh (2018). A checklist of reptiles of India. Zoological Survey of India. Date of Download : 27/12/2020. https://zsi.gov.in/checklist/Reptiles

Ahmed, M.F., A. Das \& S.K. Dutta (2009). Amphibians and Reptiles of Northeast India: A Photographic Guide. Aaranyak, Guwahati, xiv+170pp

Ahsan, M.F., I.K.A. Haidar \& M.M. Rahman (2015). Status and diversity of snakes (Reptilia: Squamata: Serpentes) at the Chittagong University Campus in Chittagong, Bangladesh. Journal of Threatened Taxa 7(14): 8159-8166. https://doi.org/10.11609/ jott.2431.7.14.8159-8166

Bhosale, H.S., G.G. Gowande \& Z.A. Mirza (2019). A new species of fossorial natricid snakes of the genus Trachischium Günther, 1858 (Serpentes: Natricidae) from the Himalayas of northeastern India. Comptes Rendus - Biologies 342(9-10): 323-329. https://doi. org/10.1016/j.crvi.2019.10.003

Bhupathy, S., S.R. Kumar, J. Paramanandham, P.T. Nathan \& S.P. Kumar (2013). Conservation of reptiles in Nagaland, India. Bioresources and Traditional Knowledge of Northeast India. Mizo Post Graduate Science Society (MIPOGRASS), Sikulpuikawn, Aizawl, 181-186pp.

Captain, A., V. Deepak, R. Pandit, B. Bhatt \& R. Athreya (2019). A new species of pitviper (Serpentes: Viperidae: Trimeresurus Lacepède, 1804) from west Kameng District, Arunachal Pradesh, India. Russian Journal of Herpetology 26(2): 111-122. https://doi. org/10.30906/1026-2296-2019-26-2-111-122

Chaida, L., A. Das, U. Tshering \& D. Wangdi (2020). Assamese Cat Snake Boiga quincunciata (Wall, 1908) (Reptilia: Squamata: Colubridae)new country record for Bhutan. Journal of Threatened Taxa 12(5): 15664-15667. https://doi.org/10.11609/JoTT.5597.12.5.1566415667

Choudhary, B. K., Majumdar, K., \& Datta, B. K. (2019). Potential Biomass Pools and Edaphic Properties of Plantation Forest in Tripura, India. International Journal of Ecology and Environmental Sciences 45(4): 369-381.

Choure, G., P. Kashyap, S. Adhikari \& H.T. Lalremsanga (2020). First Record of the Arrowback Tree Snake, Boiga gocool (Gray 1835) (Reptilia: Squamata: Colubridae), from Uttar Pradesh, India. Reptiles \& Amphibians 27(3): 436-437.
Das, A., V. Deepak, A. Captain, E.O.Z. Wade \& D.J. Gower (2020). Description of a new species of Smithophis Giri et al. 2019 (Serpentes: Colubridae: Natricinae) from Arunachal Pradesh, India. Zootaxa 4860(2): 267-283. https://doi.org/10.11646/zootaxa.4860.2.8

Das, A., D.J. Gower \& V. Deepak (2020). Lost and found: Rediscovery and systematics of the Northeast Indian snake Hebius pealii (Sclater, 1891). Vertebrate Zoology 70(3): 305-318. https://doi. org/10.26049/VZ70-3-2020-04

Das, A., P.P. Mohapatra, J. Purkayastha, S. Sengupta, S.K. Dutta, M.F. Ahmed \& F. Tillack (2010). A Contribution to Boiga gokool (Gray, 1835) (Reptilia: Squamata: Colubridae). Russian Journal of Herpetology 17(3): 161-178.

Das, A., P. Sharma, H. Surendran, A. Nath, S. Ghosh, D. Dutta, J. Mondal \& Y. Wangdi (2016). Additions to the herpetofauna of Royal Manas National Park, Bhutan, with six new country records. Herpetology Notes 9(November): 261-278.

Giri, V.B., D.J. Gower, A. Das, H.T. Lalremsanga, S. Lalronunga, A. Captain \& V. Deepak (2019). A new genus and species of natricine snake from northeast India. Zootaxa 4603(2): 241-264. https://doi. org/10.11646/zootaxa.4603.2.2

Lalremsanga, H.T. \& S. Lalronunga (2017). Mizoram rul Chanchin. Biodiversity and Nature Conservation Network (BIOCONE) B-27, Mission Veng, Aizawal, Mizoram, 129pp.

Lalremsanga, H.T. (2018). First Record of the Species Gongylosoma scriptum (Theobald, 1868) (Squamata: Colubridae) From India. Hamadryad 38(1): 12-19.

Majumder, J., P.P. Bhattachajee, K. Majumdar, C. Debnath \& B.K. Agarwala (2012). Documentation of herpetofaunal species richness in Tripura, northeast India. NeBIO 3(1): 60-70.

Mirza, Z.A., H.S. Bhosale, P.U. Phansalkar, M. Sawant, G.G. Gowande \& H. Patel (2020). A new species of green pit vipers of the genus Trimeresurus Lacepede, 1804 (Reptilia, Serpentes, Viperidae) from western Arunachal Pradesh, India. Zoosystematics and Evolution 96(1): 123-138. https://doi.org/10.3897/ZSE.96.48431

Mohalik, R.K., P.P. Mohapatra, P. Mardaraj, S. Sahoo, A.K. Bhilala, N.B. Kar \& S.K. Dutta (2020). First record of Boiga gokool (Gray, 1835)(Reptilia: Squamata: Colubridae) from Northern Odisha with notes on morphology and natural history. Records of the Zoological Survey of India-A Journal of Indian Zoology 120(2): 189-192.

Purkayastha, J. \& P. David (2019). A new species of the snake genus hebius thompson from northeast India (Squamata: Natricidae). Zootaxa 4555(1): 79-90. https://doi.org/10.11646/zootaxa.4555.1.6

Purkayastha, J., N. Khan \& S. Roychoudhury (2020). A preliminary checklist of herpetofauna occurring in Rowa Wildlife Sanctuary, Tripura, India. Environmental Science and Engineering. Springer International Publishing, 225-233pp.

Rahman, S.C., S.M.A. Rashid, K. Das \& L. Luiselli (2013). Composition and structure of a snake assemblage in an altered tropical forest-plantation mosaic in Bangladesh 34: 41-50. https://doi. org/10.1163/15685381-00002867

Sheht, C. \& A. Zambre (2012). A new Record of Boiga gokool (Gray, 1835) (Reptilia: Colubridae) from western Arunachal Pradesh, India. Sauria 34(3): 51-54.

Vogel, G., H.T. Lalremsanga \& A. Vanlalhrima (2017). A second species of the genus Blythia Theobald, 1868 (Squamata: Colubridae) from Mizoram. Zootaxa 4276(4): 569-581. https://doi.org/10.11646/ zootaxa.4276.4.8

Vogel, G., T. van Nguyen, H.T. Lalremsanga, L. Biakzuala, V. Hrima \& N.A. Poyarkov (2020). Taxonomic reassessment of the Pareas margaritophorusmacularius species complex (Squamata, Pareidae). Vertebrate Zoology 70(4): 547-569. https://doi.org/10.26049/ VZ70-4-2020-02

Wallach, V., K.L. Williams \& J. Boundy (2014). Snakes of the world: a catalogue of living and extinct species. CRC press, USA, 1237 pp.

Whitaker, R. \& A. Captain (2008). Snakes of India: The Field Guide. Draco Books, Chennai, India, 273pp. 

Dr. Albert G. Orr, Griffith University, Nathan, Australia

Dr. Sameer Padhye, Katholieke Universiteit Leuven, Belgium

Dr. Nancy van der Poorten, Toronto, Canada

Dr. Kareen Schnabel, NIWA, Wellington, New Zealand

Dr. R.M. Sharma, (Retd.) Scientist, Zoological Survey of India, Pune, India

Dr. Manju Siliwal, WILD, Coimbatore, Tamil Nadu, India

Dr. G.P. Sinha, Botanical Survey of India, Allahabad, India

Dr. K.A. Subramanian, Zoological Survey of India, New Alipore, Kolkata, India

Dr. P.M. Sureshan, Zoological Survey of India, Kozhikode, Kerala, India

Dr. R. Varatharajan, Manipur University, Imphal, Manipur, India

Dr. Eduard Vives, Museu de Ciències Naturals de Barcelona, Terrassa, Spain

Dr. James Young, Hong Kong Lepidopterists' Society, Hong Kong

Dr. R. Sundararaj, Institute of Wood Science \& Technology, Bengaluru, India

Dr. M. Nithyanandan, Environmental Department, La Ala Al Kuwait Real Estate. Co. K.S.C., Kuwait

Dr. Himender Bharti, Punjabi University, Punjab, India

Mr. Purnendu Roy, London, UK

Dr. Saito Motoki, The Butterfly Society of Japan, Tokyo, Japan

Dr. Sanjay Sondhi, TITLI TRUST, Kalpavriksh, Dehradun, India

Dr. Nguyen Thi Phuong Lien, Vietnam Academy of Science and Technology, Hanoi, Vietnam

Dr. Nitin Kulkarni, Tropical Research Institute, Jabalpur, India

Dr. Robin Wen Jiang Ngiam, National Parks Board, Singapore

Dr. Lional Monod, Natural History Museum of Geneva, Genève, Switzerland.

Dr. Asheesh Shivam, Nehru Gram Bharti University, Allahabad, India

Dr. Rosana Moreira da Rocha, Universidade Federal do Paraná, Curitiba, Brasil

Dr. Kurt R. Arnold, North Dakota State University, Saxony, Germany

Dr. James M. Carpenter, American Museum of Natural History, New York, USA

Dr. David M. Claborn, Missouri State University, Springfield, USA

Dr. Kareen Schnabel, Marine Biologist, Wellington, New Zealand

Dr. Amazonas Chagas Júnior, Universidade Federal de Mato Grosso, Cuiabá, Brasil

Mr. Monsoon Jyoti Gogoi, Assam University, Silchar, Assam, India

Dr. Heo Chong Chin, Universiti Teknologi MARA (UiTM), Selangor, Malaysia

Dr. R.J. Shiel, University of Adelaide, SA 5005, Australia

Dr. Siddharth Kulkarni, The George Washington University, Washington, USA

Dr. Priyadarsanan Dharma Rajan, ATREE, Bengaluru, India

Dr. Phil Alderslade, CSIRO Marine And Atmospheric Research, Hobart, Australia

Dr. John E.N. Veron, Coral Reef Research, Townsville, Australia

Dr. Daniel Whitmore, State Museum of Natural History Stuttgart, Rosenstein, Germany.

Dr. Yu-Feng Hsu, National Taiwan Normal University, Taipei City, Taiwan

Dr. Keith V. Wolfe, Antioch, California, USA

Dr. Siddharth Kulkarni, The Hormiga Lab, The George Washington University, Washington,

D.C., USA

Dr. Tomas Ditrich, Faculty of Education, University of South Bohemia in Ceske

Budejovice, Czech Republic

Dr. Mihaly Foldvari, Natural History Museum, University of Oslo, Norway

Dr. V.P. Uniyal, Wildlife Institute of India, Dehradun, Uttarakhand 248001, India

Dr. John T.D. Caleb, Zoological Survey of India, Kolkata, West Bengal, India

Dr. Priyadarsanan Dharma Rajan, Ashoka Trust for Research in Ecology and the Environment (ATREE), Royal Enclave, Bangalore, Karnataka, India

\section{Fishes}

Dr. Neelesh Dahanukar, IISER, Pune, Maharashtra, India

Dr. Topiltzin Contreras MacBeath, Universidad Autónoma del estado de Morelos, México

Dr. Heok Hee Ng, National University of Singapore, Science Drive, Singapore

Dr. Rajeev Raghavan, St. Albert's College, Kochi, Kerala, India

Dr. Robert D. Sluka, Chiltern Gateway Project, A Rocha UK, Southall, Middlesex, UK

Dr. E. Vivekanandan, Central Marine Fisheries Research Institute, Chennai, India

Dr. Davor Zanella, University of Zagreb, Zagreb, Croatia

Dr. A. Biju Kumar, University of Kerala, Thiruvananthapuram, Kerala, India

Dr. Akhilesh K.V., ICAR-Central Marine Fisheries Research Institute, Mumbai Research

Centre, Mumbai, Maharashtra, India

Dr. J.A. Johnson, Wildlife Institute of India, Dehradun, Uttarakhand, India

\section{Amphibians}

Dr. Sushil K. Dutta, Indian Institute of Science, Bengaluru, Karnataka, India

Dr. Annemarie Ohler, Muséum national d'Histoire naturelle, Paris, France

\section{Reptiles}

Dr. Gernot Vogel, Heidelberg, Germany

Dr. Raju Vyas, Vadodara, Gujarat, India

Dr. Pritpal S. Soorae, Environment Agency, Abu Dubai, UAE.

Prof. Dr. Wayne J. Fuller, Near East University, Mersin, Turkey

Prof. Chandrashekher U. Rivonker, Goa University, Taleigao Plateau, Goa. India

Dr. S.R. Ganesh, Chennai Snake Park, Chennai, Tamil Nadu, India

Dr. Himansu Sekhar Das, Terrestrial \& Marine Biodiversity, Abu Dhabi, UAE
Birds

Dr. Hem Sagar Baral, Charles Sturt University, NSW Australia

Dr. Chris Bowden, Royal Society for the Protection of Birds, Sandy, UK

Dr. Priya Davidar, Pondicherry University, Kalapet, Puducherry, India

Dr. J.W. Duckworth, IUCN SSC, Bath, UK

Dr. Rajah Jayapal, SACON, Coimbatore, Tamil Nadu, India

Dr. Rajiv S. Kalsi, M.L.N. College, Yamuna Nagar, Haryana, India

Dr. V. Santharam, Rishi Valley Education Centre, Chittoor Dt., Andhra Pradesh, India

Dr. S. Balachandran, Bombay Natural History Society, Mumbai, India

Mr. J. Praveen, Bengaluru, India

Dr. C. Srinivasulu, Osmania University, Hyderabad, India

Dr. K.S. Gopi Sundar, International Crane Foundation, Baraboo, USA

Dr. Gombobaatar Sundev, Professor of Ornithology, Ulaanbaatar, Mongolia

Prof. Reuven Yosef, International Birding \& Research Centre, Eilat, Israel

Dr. Taej Mundkur, Wetlands International, Wageningen, The Netherlands

Dr. Carol Inskipp, Bishop Auckland Co., Durham, UK

Dr. Tim Inskipp, Bishop Auckland Co, Durham, UK

Dr. V. Gokula, National College, Tiruchirappalli, Tamil Nadu, India

Dr. Arkady Lelej, Russian Academy of Sciences, Vladivostok, Russia

Dr. Simon Dowell, Science Director, Chester Zoo, UK

Dr. Mário Gabriel Santiago dos Santos, Universidade de Trás-os-Montes e Alto Douro,

Quinta de Prados, Vila Real, Portugal

Dr. Grant Connette, Smithsonian Institution, Royal, VA, USA

Dr. M. Zafar-ul Islam, Prince Saud Al Faisal Wildlife Research Center, Taif, Saudi Arabia

Mammals

Dr. Giovanni Amori, CNR - Institute of Ecosystem Studies, Rome, Italy

Dr. Anwaruddin Chowdhury, Guwahati, India

Dr. David Mallon, Zoological Society of London, UK

Dr. Shomita Mukherjee, SACON, Coimbatore, Tamil Nadu, India

Dr. Angie Appel, Wild Cat Network, Germany

Dr. P.O. Nameer, Kerala Agricultural University, Thrissur, Kerala, India

Dr. Ian Redmond, UNEP Convention on Migratory Species, Lansdown, UK

Dr. Heidi S. Riddle, Riddle's Elephant and Wildlife Sanctuary, Arkansas, USA

Dr. Karin Schwartz, George Mason University, Fairfax, Virginia.

Dr. Lala A.K. Singh, Bhubaneswar, Orissa, India

Dr. Mewa Singh, Mysore University, Mysore, India

Dr. Paul Racey, University of Exeter, Devon, UK

Dr. Honnavalli N. Kumara, SACON, Anaikatty P.O., Coimbatore, Tamil Nadu, India

Dr. Nishith Dharaiya, HNG University, Patan, Gujarat, India

Dr. Spartaco Gippoliti, Socio Onorario Società Italiana per la Storia della Fauna "Giuseppe

Altobello", Rome, Italy

Dr. Justus Joshua, Green Future Foundation, Tiruchirapalli, Tamil Nadu, India

Dr. H. Raghuram, The American College, Madurai, Tamil Nadu, India

Dr. Paul Bates, Harison Institute, Kent, UK

Dr. Jim Sanderson, Small Wild Cat Conservation Foundation, Hartford, USA

Dr. Dan Challender, University of Kent, Canterbury, UK

Dr. David Mallon, Manchester Metropolitan University, Derbyshire, UK

Dr. Brian L. Cypher, California State University-Stanislaus, Bakersfield, CA

Dr. S.S. Talmale, Zoological Survey of India, Pune, Maharashtra, India

Prof. Karan Bahadur Shah, Budhanilakantha Municipality, Kathmandu, Nepal

Dr. Susan Cheyne, Borneo Nature Foundation International, Palangkaraja, Indonesia

Dr. Hemanta Kafley, Wildlife Sciences, Tarleton State University, Texas, USA

\section{Other Disciplines}

Dr. Aniruddha Belsare, Columbia MO 65203, USA (Veterinary)

Dr. Mandar S. Paingankar, University of Pune, Pune, Maharashtra, India (Molecular)

Dr. Jack Tordoff, Critical Ecosystem Partnership Fund, Arlington, USA (Communities)

Dr. Ulrike Streicher, University of Oregon, Eugene, USA (Veterinary)

Dr. Hari Balasubramanian, EcoAdvisors, Nova Scotia, Canada (Communities)

Dr. Rayanna Hellem Santos Bezerra, Universidade Federal de Sergipe, São Cristóvão, Brazil

Dr. Jamie R. Wood, Landcare Research, Canterbury, New Zealand

Dr. Wendy Collinson-Jonker, Endangered Wildlife Trust, Gauteng, South Africa

Dr. Rajeshkumar G. Jani, Anand Agricultural University, Anand, Gujarat, India

Dr. O.N. Tiwari, Senior Scientist, ICAR-Indian Agricultural Research Institute (IARI), New

Delhi, India

Dr. L.D. Singla, Guru Angad Dev Veterinary and Animal Sciences University, Ludhiana, India

Dr. Rupika S. Rajakaruna, University of Peradeniya, Peradeniya, Sri Lanka

Dr. Bahar Baviskar, Wild-CER, Nagpur, Maharashtra 440013, India

Reviewers 2018-2020

Due to pausity of space, the list of reviewers for 2018-2020 is available online.
The opinions expressed by the authors do not reflect the views of the Journal of Threatened Taxa, Wildlife Information Liaison Development Society, Zoo Outreach Organization, or any of the partners. The journal, the publisher, the host, and the partners are not responsible for the accuracy of the political boundaries shown in the maps by the authors.

\footnotetext{
Print copies of the Journal are available at cost. Write to:

The Managing Editor, JoTT,

c/o Wildlife Information Liaison Development Society,

No. 12, Thiruvannamalai Nagar, Saravanampatti - Kalapatti Road,

Saravanampatti, Coimbatore, Tamil Nadu 641035, India

ravi@threatenedtaxa.org
} 


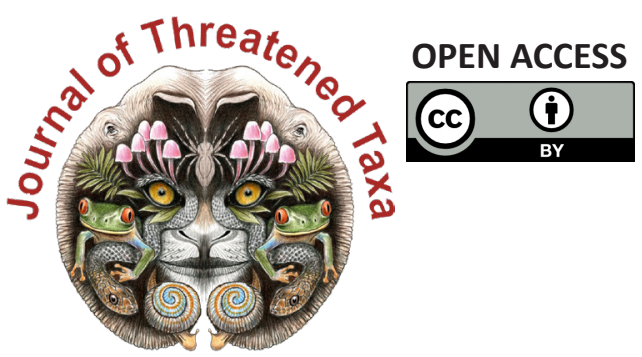

www.threatenedtaxa.org

The Journal of Threatened Taxa (JoTT) is dedicated to building evidence for conservation globally by publishing peer-reviewed articles online every month at a reasonably rapid rate at www.threatenedtaxa.org. All articles published in JoTT are registered under Creative Commons Attribution 4.0 International License unless otherwise mentioned. JoTT allows allows unrestricted use, reproduction, and distribution of articles in any medium by providing adequate credit to the author(s) and the source of publication.

\section{ISSN $0974-7907$ (Online) | ISSN $0974-7893$ (Print)}

\section{September 2021 | Vol. 13 | No. 11 | Pages: 19431-19674 Date of Publication: 26 September 2021 (Online \& Print) DOI: 10.11609/jott.2021.13.11.19431-19674}

Articles

Understanding human-flying fox interactions in the Agusan Marsh Wildlife Sanctuary as basis for conservation policy interventions

- Sherryl L. Paz \& Juan Carlos T. Gonzalez, Pp. 19431-19447

Argentinian odonates (dragonflies and damselflies): current and future distribution and discussion of their conservation

- A. Nava-Bolaños, D.E. Vrech, A.V. Peretti \& A. Córdoba-Aguilar, Pp. 19448-19465

\section{Communications}

The diel activity pattern of small carnivores of Western Ghats, India: a case study at Nelliampathies in Kerala, India

- Devika Sanghamithra \& P.O. Nameer, Pp. 19466-19474

Distribution and threats to Smooth-Coated Otters Lutrogale perspicillata (Mammalia: Carnivora: Mustelidae) in Shuklaphanta National Park, Nepal

- Gopi Krishna Joshi, Rajeev Joshi \& Bishow Poudel, Pp. 19475-19483

Wildlife hunting practices of the Santal and Oraon communities in Rajshahi, Bangladesh - Azizul Islam Barkat, Fahmida Tasnim Liza, Sumaiya Akter, Ashikur Rahman Shome \& M. Fazle Rabbe, Pp. 19484-19491

Ethnozoological use of primates in northeastern India

- Deborah Daolagupu, Nazimur Rahman Talukdar \& Parthankar Choudhury, Pp. 19492-19499

Factors influencing the flush response and flight initiation distance of three owl species in the Andaman Islands

- Shanmugavel Sureshmarimuthu, Santhanakrishnan Babu, Honnavalli Nagaraj Kumara \& Nagaraj Rajeshkumar, Pp. 19500-19508

Birds of Barandabhar Corridor Forest, Chitwan, Nepal

- Saneer Lamichhane, Babu Ram Lamichhane, Kapil Pokharel, Pramod Raj Regmi, Tulasi Prasad Dahal, Santosh Bhattarai, Chiranjibi Prasad Pokheral, Pabitra Gotame,

Trishna Rayamajhi, Ram Chandra Kandel \& Aashish Gurung, Pp. 19509-19526

On some additions to the amphibians of Gunung Inas Forest Reserve, Kedah,

Peninsular Malaysia

- Shahriza Shahrudin, Pp. 19527-19539

Reviews

A review of research on the distribution, ecology, behaviour, and conservation of the Slender Loris Loris lydekkerianus (Mammalia: Primates: Lorisidae) in India

- Mewa Singh, Mridula Singh, Honnavalli N. Kumara, Shanthala Kumar, Smitha D. Gnanaolivu \& Ramamoorthy Sasi, Pp. 19540-19552

Bivalves (Mollusca: Bivalvia) in Malaysian Borneo: status and threats

- Abdulla-Al-Asif, Hadi Hamli, Abu Hena Mustafa Kamal, Mohd Hanafi Idris, Geoffery James Gerusu, Johan Ismail \& Muyassar H. Abualreesh, Pp. 19553-19565

Disentangling earthworm taxonomic stumbling blocks using molecular markers

- Azhar Rashid Lone, Samrendra Singh Thakur, Nalini Tiwari, Olusola B. Sokefun \&

Shweta Yadav, Pp. 19566-19579

A reference of identification keys to plant-parasitic nematodes (Nematoda: Tylenchida) Tylenchomorpha)

- Reza Ghaderi, Manouchehr Hosseinvand \& Ali Eskandari, Pp. 19580-19602

Short Communications

Catalogue of herpetological specimens from Meghalaya, India at the Salim Ali Centre for Ornithology and Natural History

-S.R. Chandramouli, R.S. Naveen, S. Sureshmarimuthu, S. Babu, P.V. Karunakaran \&

Honnavalli N. Kumara, Pp. 19603-19610
A preliminary assessment of odonate diversity along the river Tirthan, Great Himalayan National Park Conservation Area, India with reference to the impact of climate change - Amar Paul Singh, Kritish De, Virendra Prasad Uniyal \& Sambandam Sathyakumar, Pp. 19611-19615

A checklist of orthopteran fauna (Insecta: Orthoptera) with some new records in the cold arid region of Ladakh, India

- M. Ali, M. Kamil Usmani, Hira Naz, Tajamul Hassan Baba \& Mohsin Ali, Pp. 19616-19625

New distribution records of two Begonias to the flora of Bhutan

- Phub Gyeltshen \& Sherab Jamtsho, Pp. 19626-19631

Rediscovery of Aponogeton lakhonensis A. Camus (Aponogetonaceae): a long-lost aquatic plant of India

- Debolina Dey, Shrirang Ramchandra Yadav \& Nilakshee Devi, Pp. 19632-19635

Glyphochloa acuminata (Hack.) Clayton var. laevis (Poaceae): a new variety from central Western Ghats of Karnataka, India

- H.U. Abhijit \& Y.L. Krishnamurthy, Pp. 19636-19639

A cytomorphological investigation of three species of the genus Sonchus L. (Asterales: Asteraceae) from Punjab, India

- M.C. Sidhu \& Rai Singh, Pp. 19640-19644

Dryopteris lunanensis (Dryopteridaceae) - an addition to the pteridophytic diversity of India

- Chhandam Chanda, Christopher Roy Fraser-Jenkins \& Vineet Kumar Rawat, Pp. 1964519648

Notes

First record of Spotted Linsang Prionodon pardicolor (Mammalia: Carnivora:

Prionodontidae) with photographic evidence in Meghalaya, India

- Papori Khatonier \& Adrian Wansaindor Lyngdoh, Pp. 19649-19651

First record of the Eastern Cat Snake Boiga gocool (Gray, 1835) (Squamata: Colubridae) from Tripura, India

- Sumit Nath, Biswajit Singh, Chiranjib Debnath \& Joydeb Majumder, Pp. 19652-19656

First record of the genus Tibetanja (Lepidoptera: Eupterotidae: Janinae) from India - Alka Vaidya \& H. Sankararaman, Pp. 19657-19659

Austroborus cordillerae (Mollusca: Gastropoda) from central Argentina: a rare, little-known land snail

- Sandra Gordillo, Pp. 19660-19662

Intestinal coccidiosis (Apicomplexa: Eimeriidae) in a Himalayan Griffon Vulture Gyps himalayensis

- Vimalraj Padayatchiar Govindan, Parag Madhukar Dhakate \& Ayush Uniyal, Pp. 1966319664

Two new additions to the orchid flora of Assam, India

- Sanswrang Basumatary, Sanjib Baruah \& Lal Ji Singh, Pp. 19665-19670

Wildlife art and illustration - combining black and white ink drawings with colour: some experiments in Auroville, India

- M. Eric Ramanujam \& Joss Brooks, Pp. 19671-19674
Publisher \& Host

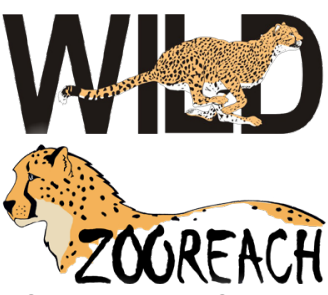

